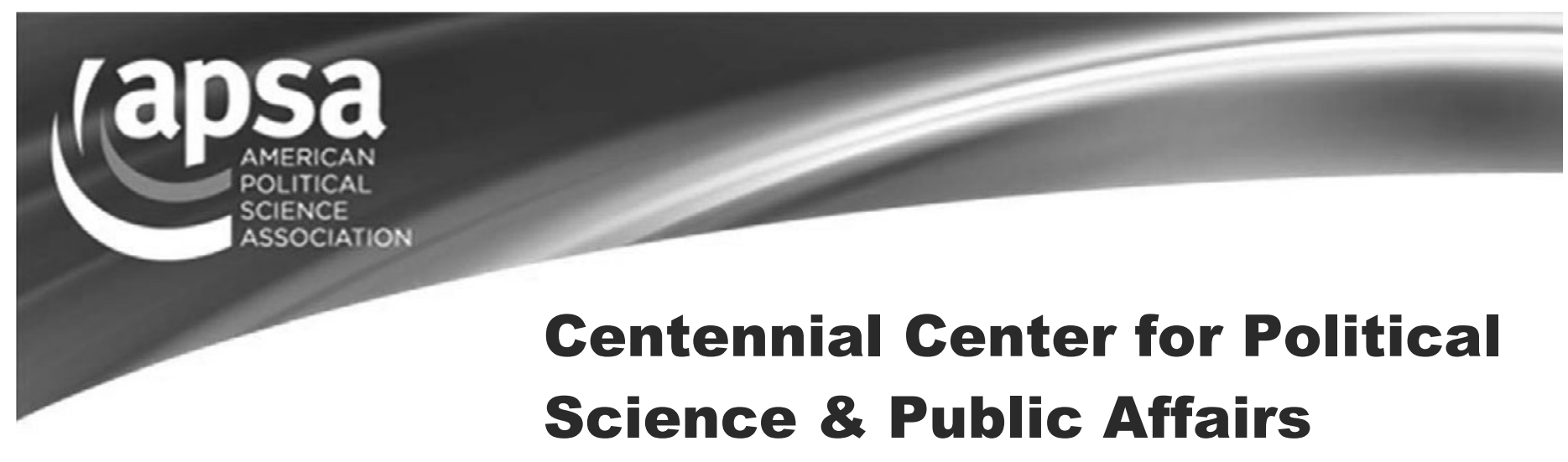

\section{About the Centennial Center}

Since 2003, the APSA

Centennial Center for

Political Science \& Public

Affairs encourages

individual research and

writing in all fields of political

science, facilitates

collaboration among

scholars working within the

discipline and across the

social and behavioral

sciences and humanities,

and promotes

communication between

scholars and policymakers.

Through its Washington, DC

facilities and endowed

funding programs, the

Centennial Center

'celebrates the past by

investing in the future.'

The Center, its residential facilities, and supplemental awards are made possible in part through the generous donations of APSA members. To learn more about supporting the Centennial Center or holding an event in Washington, please contact centennial@apsanet.org.

\title{
2014-2015 Opportunities
}

n 2014-2015, the Centennial Center will provide Residential

Research Fellowships at the

APSA national offices in

Washington, DC, and

\section{Supplemental Research Awards}

to scholars conducting research

anywhere in the world.

\section{Residential Research \\ Fellowships}

The Center assists scholars from the United States and abroad whose research and teaching would benefit from a stay in Washington, DC and access to the incomparable resources that are available in the nation's capital. The Center hosts up to seven scholars for extended periods of time, ranging from weeks to months. Space for shorter "drop-in" stays is also available. Scholars are expected to pursue their own research and teaching projects and contribute to the intellectual life of the residential community by sharing their work with Center colleagues in occasional informal seminars.

Located within the Association's headquarters building near Dupont
Circle, with easy access to the Washington Metro system, the Center offers visiting scholars furnished shared work space, telephone, fax, personal computers, Internet connection, conference space, a reference library, and library access at the George Washington University.

\section{Supplemental Research Awards}

Open to APSA members, the Center also provides supplemental research awards to support scholars working at the Centennial Center or other research locations. In 2014-2015, funds will support direct research costs, travel to APSA and other academic meetings, joint research projects, and "The Centennial Center has given me an excellent base in Washington. I can't imagine how stressful my sabbatical would have been without all the support." programs to assist early career scholars in publishing their research. To learn about eligibility, how to apply, and more please visit www.apsanet.org or email centennial@apsanet.org. 


\section{KANSAS}
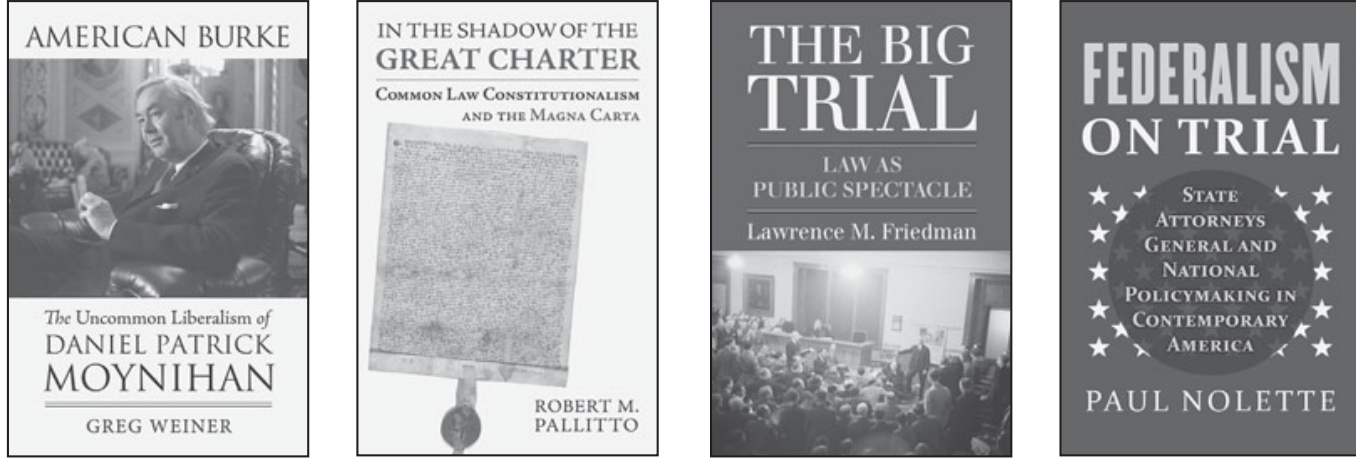

PURSUING

HORIZONTAL

MANAGEMENT

\section{American Burke}

\section{The Uncommon Liberalism of Daniel Patrick Moynihan} Greg Weiner

"Few American senators of the past century would be worthy of an extended study of their political philosophy, but Daniel Patrick Moynihan certainly was. American Burke is a fascinating and brilliant account of what was an unusual political philosophy for a successful American politician-a liberal, yes, but one aware of the complexity of society and social institutions, the difficulty of molding or remolding them, the worth of traditional institutions and arrangements, and yes, something of an American Burke. And all this was expressed in the most engaging and sparkling style of any political figure of recent generations. Whatever else is written of Moynihan, and there will be much, this will stand as a classic."

-Nathan Glazer, author of We Are All Multiculturalists Now

"Like James Madison, Daniel Patrick Moynihan was the most interesting public intellectual of his day and he refined his systematic political thinking during decades in the practice of politics. Greg Weiner's masterful exegesis demonstrates that Moynihan's robust liberalism was informed, but never deformed, by his Burkean sense of the purposes and limits of politics." -George F. Will, columnist for the Washington Post

American Political Thought 208 pages, Cloth $\$ 27.95$, Ebook $\$ 27.95$

\section{In the Shadow of the Great Charter} Common Law Constitutionalism and the Magna Carta

Robert M. Pallitto

"Pallitto thoroughly explores the historical and contemporary influence of the Magna Carta on law and courts in the United States, including in cases on the issues of slavery, the incorporation of the Bill of Rights, the writ of habeas corpus, and individual liberties during the "war on terror."'-Eric T. Kasper, author of Impartial Justice: The Real Supreme Court Cases that Define the Constitutional Right to a Neutral and Detached Decisionmaker 248 pages, Cloth \$29.95, Ebook \$29.95

\section{The Big Trial}

\section{Law as Public Spectacle}

Lawrence M. Friedman

"Lawrence Friedman, our legal historian with the widest range, explains the great variety in courtroom and related events that have attracted our attention in American history. His book is a must for anyone who becomes absorbed in a high-profile trial." - Robert A. Ferguson, George Edward Woodberry Professor in Law, Literature, and Criticism at Columbia Law School

232 pages, Cloth $\$ 29.95$, Ebook $\$ 29.95$
Federalism on Trial State Attorneys General and National Policymaking in Contemporary America

Paul Nolette

"In this eye-opening book, Paul Nolette illuminates an increasingly important feature of America's uniquely litigious system of regulation and governance —coordinated policy-oriented lawsuits by state attorneys general. . . . Essential reading for scholars, teachers, and students interested in the interaction of law and politics, in federalism, and in the politics of public policy."--Robert A. Kagan, Center for the Study of Law and Society at University of California, Berkeley

288 pages, Cloth $\$ 37.50$, Ebook $\$ 37.50$

\section{Pursuing Horizontal Management} The Politics of Public Sector Coordination

\section{B. Guy Peters}

"Guy Peters gives us a comprehensive inside view of the Holy Grail of Coordination. In this book we benefit from his vast international experience, his capacity to go to the essence of horizontal management, and this critical view of coordination as part of a problem but also as part of a solution."-Geert Bouckaert, President of the International Institute of Administrative Sciences Studies in Government and Public Policy 216 pages, 8 illustrations, Cloth $\$ 50.00$, Paper $\$ 22.50$

\section{University Press of Kansas}

Phone 785-864-4155 • Fax 785-864-4586 • www.kansaspress.ku.edu 


\section{$1^{111^{\text {th }}}$ APSA ANNUAL MEETING SEPTEMBER 3-6, 2015 | SAN FRANCISCO, CA}

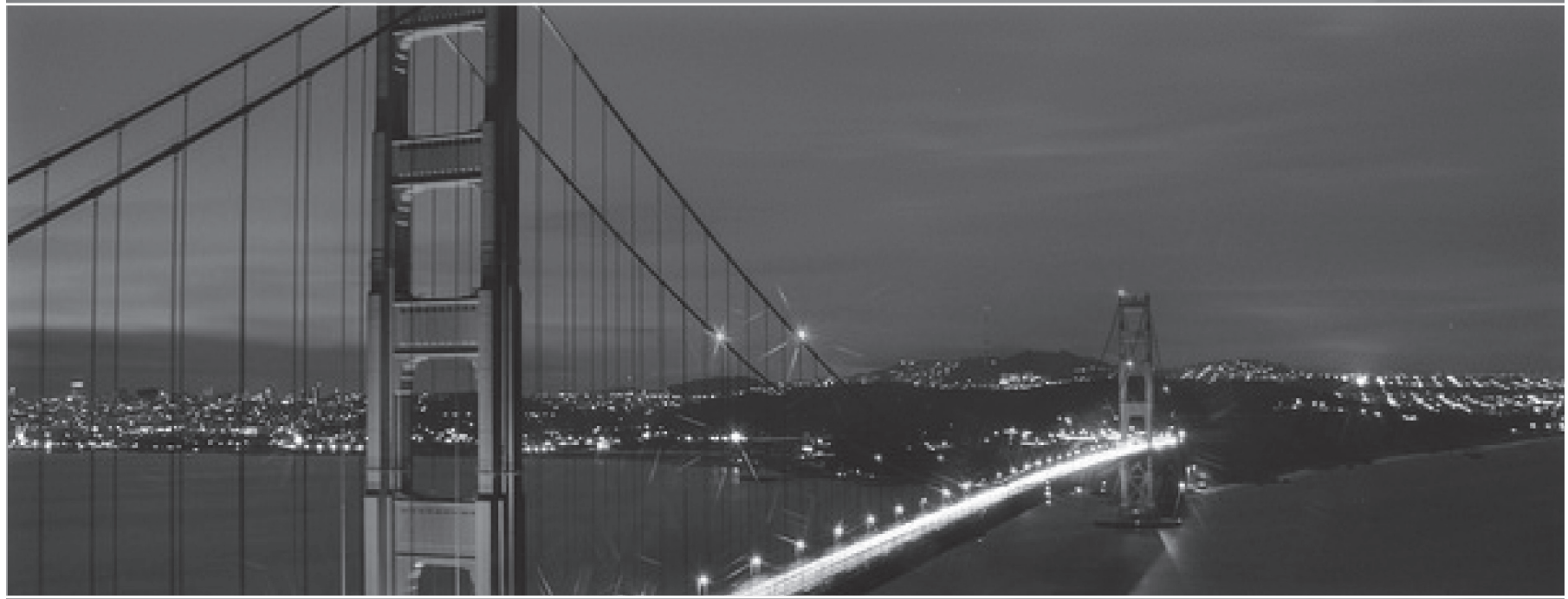

\section{REGISTRATION OPENS IN MARCH!}

Engage with 6,500 of your colleagues and address the latest scholarship in political science while exploring this year's theme:

Diversities Reconsidered: Politics $\&$ Political Science in the $21^{\text {st }}$ Century

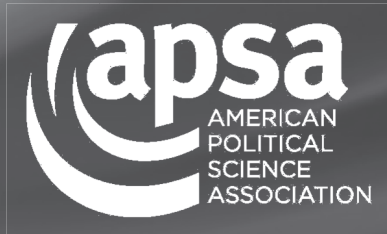

www.apsanet.org 